TEME, г. XLII, бр. 3, јул - септембар 2018, стр. 877-897

Претходно саопштење

DOI: $10.22190 /$ TEME1803877S

Примљено: 17. 5. 2017.

UDK 371.213.3(497.11)

Ревидирана верзија: 2. 12. 2017.

Одобрено за штампу: 12. 6. 2018.

\title{
МЕНТОРСКИ РАД У СРБИЈИ - КОНТУРЕ ЈЕДНЕ ТИПОЛОГИЗАЦИЈЕ
}

\section{Тања Шијаковић}

Завод за унапређивање образовања и васпитања, Београд, Србија

tanja.sijakovic@zuov.gov.rs

\begin{abstract}
Апстракт
Као вишеструко условљен релациони феномен, менторство и пракса коју заједнички обављају приправник и ментор привлаче пажњу истраживача у различитим областима рада. Са намером да усмеримо пажњу на овај део образовне праксе код нас, спровели смо истраживање у чијем средишту интересовања су била питања о приправништву и менторству у образовању. Иако су нашу пажњу окупирала првенствено питања која су се односила на разумевање концепције приправништва и менторства и начина на који се решења која она нуди рефлектују у актуелној пракси приправника и ментора, истраживање је неочекивано резултирало још једним налазом - могућим типовима менторског рада у нашем образовном контексту. До резултата се дошло након анализе транскрибованог материјала, прикупљеног у појединачно вођеним интервјуима са десет ментора. Откривени, различити приступи менторском раду засновани су на анализи одговора и тумачењима која су ментори давали у вези са: разумевањем функције менторског рада; очекивањима која имају од приправника; сагледавањем улога приправника и ментора; разумевањем учења и значајем планирања рада са приправником. Тумачећи начин на који разумеју претходно поменуто и описујући конкретан рад са својим приправницима, издвојени су ментори који су испољили конзистентне језичко-искуствене обрасце и ставове, међусобно довољно различите да могу да чине обрисе посебних типова менторстава, у раду препознатих као: ad hoc менторство, форма-менторство и развојно менторство.
\end{abstract}

Кључне речи: ментор, типови менторског рада, ad hoc менторство, формаменторство, развојно менторство.

\section{MENTORING IN EDUCATION - THE CONTOURS OF POSSIBLE TYPOLOGIES}

\begin{abstract}
As a highly complex relational phenomenon, mentoring and practice which are jointly carried out by an intern and a mentor, attracted the attention of researchers in different fields. With the aim to draw attention to this part of the educational practice
\end{abstract}


in our environment, we carried out a research which focuses on issues of internship and mentoring in education. Although our attention was focused primarily on the issues related to understanding the concept of internships and mentoring and how the offered solutions would reflect in the practice of interns and mentors, research has unexpectedly resulted in some additional findings - the possible types of mentoring in our educational context.Shown results were achieved after analysis of the transcribed material collected in individual interviews, conducted by ten mentors. All the discovered and different approaches to mentoring work are based on an analysis of responses and interpretations that were given by the mentors themselves, and related to: understanding the functions of mentoring; expectations from the interns; understanding the role of interns and mentors; understanding the process of learning and the importance of planning the work with interns. Interpreting the way mentors understand aforesaid and describing specific relation with their interns, we have selected mentors who have demonstrated a consistent linguistic experiential patterns and positions, mutually so different, that they can make the contours of different types of mentoring. In the paper these specific types are identified as: adhoc, formal and development mentoring.

Key words: mentor, types of mentoring work, ad hoc mentoring, formal mentoring, development mentoring.

\author{
„Мислим да сам ја томе пришла некако \\ више спонтано него што сам смела. Као да нисам \\ сама са собом довољно села и размислила шта \\ то менторство све значи."
}

(Из интервјуа испитаника М3: мај 2014)

\begin{abstract}
УВОД
Проблеми са којима се суочавају наставници почетници нису искључиви и нису везани за одређену земљу или поднебље. Управо супротно, истраживања показују да наставници почетници у различитим образовним системима имају зачуђујуће слична мишљења о изазовима са којима се суочавају. Међу најчешће навођеним изазовима, у великом међународном истраживању Винмана (Veenman, 1984) наставници почетници издвајали су следеће: мотивисање ученика на учење, управљање у учионици, обезбеђивање индивидуалног приступа ученику, оцењивање ученика и комуникација са родитељима. У једној новијој међународној студији (Britton at al, 2003) потврђени су налази претходно наведеног истраживања, односно исти проблеми и даље су најтежи изазови за велики број испитаних наставника почетника. Неке земље на поменуте изазове одговарају креирањем програма̂ за увођење наставника у посао, односно практиковањем приправничког периода за наставнике, током кога они уживају помоћ и подршку старијег наставника. Овакав одговор про-
\end{abstract}


светних власти ослања се на претпоставку да квалитет професионалног искуства на самом почетку рада може имати далекосежне последице по будућу праксу наставника у учионици и каријеру коју ће наставник градити. Добро осмишљени и развијени програми увођења наставника у посао носе потенцијал не само да помогну почетницима да лакше прођу кроз прве године рада у школи већ да у сигурном окружењу унапређујући своје потенцијале граде идентитет наставника професионалца. Наравно, колико ће се то заиста дешавати у стварности зависи од начина на који се програми доносе (централизовано или укључујући оне на које се програм односи), од квалитета програма (нпр., јасност циља, дефинисаност исхода, временска организација, структура програма, флексибилност и сл.), затим од начина на који приправници и ментори разумеју и прихватају дефинисани програм, као и од културе образовне установе у којој се менторско-приправничка пракса остварује.

У оквирима различитих образовних система користе се разноврсни приступи и програми за увођење наставника у посао, при чему квалитет и садржај програма увелико варирају. Стансбери и Цимерман (Stansbury \& Zimmerman, 2000) деле програме подршке наставницима приправницима на програме ниског и високог интензитета (ibid, стр. 6). Према овим ауторима, програми ниског интензитета обезбеђују формалну оријентацију кроз један тренинг или неколико тренинга. Они мање коштају, али и дају лошије резултате од програма подршке високог интензитета који подразумевају менторство током дужег периода и захтевају пуну координацију са другим школским активностима (менторска пракса интегрални део праксе школе у целини, прим. аутора).

Према извештају ОЕЦД-а (y: McGaw, 2005) који се ослања на искуства земаља чланица, програми увођења нових наставника у посао не само да се разликују него их један број земаља још увек и нема. Од укупно тридесет земаља ове групације, у поменутом извештају у делу који се односи на програме увођења у посао постоје подаци за укупно 24 земље. У том смислу, у десет земаља постоје обавезни програми увођења наставника у посао. То су неке државе у Аустралији, Енглеска и Велс, Француска, Грчка, Израел, Италија, Јапан, Кореја, Швајцарска и Северна Ирска. У Шкотској је, на пример, избор о учествовању у програмима обуке препуштен слободном избору наставника. Доступни подаци показују да се, и у оваквим условима у Шкотској, највећи број наставника одлучује за похађање понуђеног програма. У шест земаља на школском нивоу одлучује се о похађању програма за увођење у посао (Канада (Квебек), Холандија, Шведска, неке државе у САД), док у осам земаља овакви програми уопште не постоје (неке државе у Аустралији, Аустрија, Белгија, Чиле, Финска, Немачка, Мађарска, Ирска). Нарочито занимљивим чини 
нам се податак да Финска, која тренутно важи за једну од земаља са најуспешнијим системом образовања наставника, нема развијене програме менторског рада. Разлоге за непостојање програма могуће је тражити у веома озбиљном одабиру кадрова и квалитетном иницијалном образовању, где је знатан део курикулума посвећен практиковању теоријских знања у школама вежбаоницама (Salhberg, 2013). Када је реч о земљама у којима је програм увођења наставника у посао обавезан део уласка у професију, у највећем броју земаља, успешно завршавање програма предуслов је добијања лиценце за рад.

Када је реч о обезбеђивању услова за нове наставнике за похађање програма, у већини земаља на које се извештај ОЕЦД односи, школа у којој се наставник запошљава одговорна је да им обезбеди подршку у овом послу. Издвајају се Израел, Швајцарска и Северна Ирска, у којима је увођење у посао део сарадње између школа које примају новог наставника и институција за иницијално образовање наставника. У Грчкој, Кореји и Норвешкој, ови програми остварују се у сарадњи са удружењима наставника.

Трајање програма увођења наставника у посао још једна је од ставки које се могу поредити и које се такође разликују од земље до земље. Најчешће се овај период креће од седам месеци (нпр. Кореја) до две године (Квебек, Швајцарска, неки делови САД-а). У највећем броју земаља савладавање програма увођења у посао не значи истовремено смањење редовних обавеза у школи. Неки од изузетака у овој статистици су поједине државе у Аустралији (обавезе су смањене на 90-95\% редовних обавеза наставника), Енглеска и Велс (90\% редовних обавеза наставника), Француска (30\%) Израел (до $50 \%$ праксе обави се током последње године студирања) и Северна Ирска и Шкотска (70\%).

У великом броју земаља, у сарадњи са директором школе и другим наставницима, ментори су ти који организују и пружају подршку у увођењу нових наставника у посао. Ипак, мали је број земаља у којима је неопходна нека врста формалне обуке и образовања да би се успешно обављала менторска улога. У том смислу издвајају се једна држава Аустралије, Француска (само када је реч о образовању наставника за рад у нижој основној школи), Израел, Швајцарска и неке државе у САД.

Школе које саме одлучују о томе да ли ће или неће примењивати програм увођења у посао наставницима којима доделе улогу ментора најчешће нуде неку врсту компензације за уложено време и рад. Често то буде одређен број тзв. слободних дана (Квебек, Данска, Шкотска). У Шведској ментори могу бирати између „слободних дана" и финансијсе надокнаде. У земљама у којима су програми обавезни, ментори добијају финансијску надокнаду уз плате за период у коме су менторисали (Израел, Грчка, Швајцарска). 
Закон о основама система образовања и васпитања (2013), Правилник о дозволи за рад наставника, васпитача и стручних сарадника (2005. и 2008) и приручник Ментор и приправник - водич за наставнике, васпитаче и стручне сараднике (група аутора, 2009) чине скуп законских и подзаконских аката којима се регулишу статусна и концепцијска питања приправничко-менторске праксе у Сpбији. Иако у појединим деловима дисонантни (на пример, циљ приправништва и менторства се на различите начине дефинише у правилнику и приручнику), ови документи чине једини ослонац и кључне смернице за рад приправника и ментора. У том смислу, правилником је предвиђен оријентациони програм рада ментора са приправником, дефинисан у виду очекиваних исхода за крај приправничког периода у оквиру шест области рада. Прописано је и да се Програм увођења у посао завршава обавезним полагањем испита за лиценцу. Трајање приправничког периода флексибилно је дефинисано и траје од 12 месеци до 24 месеца, а рад приправника и ментора саставни су део четрдесеточасовне радне недеље и ментори нису посебно плаћени за овај посао.

Правилником је дефинисано да за ментора може бити одређен истакнути наставник, васпитач или стручни сарадник који има лиценцу, једно од прописаних звања или најмање пет година радног искуства у области образовања и васпитања. Када је реч о формалним, системским припремама за улогу ментора, Правилником је предвиђена обука за менторе у трајању од 40 сати, која може да се остварује кроз један интегрисани менторски програм или кроз већи број различитих обука које се односе на питања важна за рад ментора. У пракси, међутим, формалну обуку прошло је тек нешто више од 70 запослених, па се критеријуми за избор ментора своде на обавезни минимум од пет година радног искуства. Осим тога, према важећој законској регулативи, није предвиђено ни праћење ни оцењивање рада ментора. Наиме, за разлику од штурих и недовољно јасних критеријума на основу којих директори постављају менторе, критеријуми на основу којих се ментори поново бирају - потпуно су непознати. С обзиром на то да у образовном систему Србије бити ментор не значи имати звање ментора (у систему звања наставника које се стиче према унапред постављеним условима), идеја о програму обуке за менторе (на којој се до сада није озбиљније радило) могла би послужити као механизам којим се утиче на повећање нивоа квалитета рада ментора. 


\section{ПОЗНАТЕ ТИПОЛОГИЈЕ МЕНТОРСКОГ РАДА И ЊИХОВЕ ОСНОВЕ}

Пракса менторског рада релативно касно почела је да се истражује, и то првенствено у привреди и контексту социјалног рада, да би се с тог подручја пренела и на образовање. Условљена комплексношћу менторства, истраживачка пажња усмеравана је ка његовим различитим аспектима - од теоријских трагања за смислом и значењем појмова ментор и менторство, преко преиспитивања суштине менторског рада, његових стварних домета и могућности (Sundli, 2007), па до истраживања услова који обезбеђују успешну имплементацију менторске праксе (Tillemaetal, 2011; Sirpa\&Raija, 2012). Како истраживања постају бројнија, њихови резултати сложенији, уочавају се и разлике у приступима и раду ментора, те почиње да се пише о различитим типовима менторског рада (опширније у Шијаковић, 2013b).

У основама класификација које теорија данас познаје налазе се различити критеријуми. У том смислу, препознали смо:

а) Типологизације које почивају искључиво на одговору на питање да ли је однос између приправника и ментора формално и системски заснован и утемељен или је реч о односу који се спонтано развио и „неплански” водио ка остваривању одређених резултата. У том контексту говори се искључиво о формалном и неформалном типу менторства (Inzer \& Crawford, 2005).

б) Типологизације изграђене на одговору на питање како се током овог периода учи. Једну од најпознатијих типологизација заснованих на овом критеријуму понудили су Мајнард и Фурлонг, закључивши да је у овом контексту могуће говорити о три модела менторског рада - модел шегртовања, модел компетенција и рефлексивни модел (Maynard \& Furlong, 1995).

в) Типологизације које почивају на проучавању укупности подршке коју менторство подразумева. Ауторке Хигинс и Крам (Higgins \& Kram, 2001) у том смислу дају две широке категорије типова менторског рада. У прву категорију ауторке сврставају менторски рад који се заснива на односу један приправник - један ментор. Покрећући питање да ли је суштину менторства могуће сагледати и остварити у односу који подразумева искључиво рад једног ментора са једним приправником, ауторке предлажу разумевање менторства као вишеструко развојно релационог феномена (ibid, стр. 264). Наиме, менторство треба посматрати у оквиру теорије друштвених група и на њој заснивати методику менторског рада. У контексту менторског рада, друштвене групе чине основ модела индивидуално развојне мреже, која подразумева скуп особа које приправник именује као оне које показују активно интересовање за юегову каријеру и предузимају акције у контексту унапређивања те каријере (ibid, стр. 268). Концептом ин- 
дивидуално развојних мрежа у области менторства ауторке су покренуле низ питања везаних за методичко моделовање рада ментора и приправника - од тога ко све може да буде ментор, преко специфичних улога које би свако од њих имао, па до неопходности међусобног усаглашавања већег броја различитих ментора.

г) Типологизације засноване на свеобухватнијим приступима који трагајући за постојећим типовима менторског рада у основ својих промишљања стављају промену опажања улоге и положаја наставника и професионализацију наставничке струке. У том контексту Харгривс и Фулан (Hargreaves \& Fullan, 2009) познају четири различита модела менторског рада: модел пре професионализма, модел професионалне аутономије, модел колегијалне професионалности и модел савременог професионализма.

Када је реч о менторском раду у образовању, чини се да одређивање модела менторства у великој мери зависи од тога како дефинишемо и разумемо одговор на питање шта је уопште менторство и које су му кључне функције. У домену учења, суштина проблема везаних за менторство и његове различите типове могла би се сажети у питању: Да ли је оно учење практиковањ а или практиковање континуираног учења? (Шијаковић, 2013а, стр. 612). Одговор на ово питање сасвим сигурно усмерава и одговоре о суштини менторског рада, функцији и значају за развој наставника, као што илплищитно подразумева и одговор на питање каквог наставника и какву школу желимо (ибид).

У контексту новијих тумачења менторства, од савремених модела менторског рада очекује се да покрену иновације на пољу целокупне образовне праксе. У том смислу Харгривс и Фулан (Hargreaves \& Fullan, 2009) предлажу кретање менторства у следећим правцима: од рада у пару, ка менторству као саставном делу професионалне културе школе; од фокуса на рад у учионици до фокуса на јачање веза са колегама и родитељима; од хијерархијског односа (старији и искуснији наспрам млађег и неискусног) у коме је акценат на једносмерном саветовању до заједничког истраживања праксе; од изоловане иновације до саставног дела иновирања целокупног система образовања и усавршавања наставника.

\section{МЕТОДОЛОГИЈА ИСТРАЖИВАЬА}

Истраживање чију методологију описујемо остварено је са намером да скрене пажњу образовне јавности на важност менторског рада у образовању. Циљ нам је био да са једне стране испитамо мишљење и рефлексије ментора и приправника о непосредној пракси коју заједно реализују, а са друге стране да анализирамо како њихова пракса (на основу рефлексија које о њој дају) кореспондира 
са важећом концепцијом менторства и као таква доприноси и подржава развој рефлексивних практичара у образовању. Под синтагмом кониепиија менторства подразумевамо теоријски осмишљене и научно утемељене идеје о суштини менторског рада и остваривању професионалних улога приправника и ментора, које се путем законских и програмских докумената конкретизују кроз низ разноврсних обавеза, задатака и активности.

Полазећи од комплексности и неистражености изабраног предмета истраживања, определили смо се за квалитативну истраживачку парадигму и технику полуструктурисаног интервјуа. За сваки интервју обезбеђена је писана сагласност учесника интервјуа (Seidman, 2006), којом су учесници упознати са основном сврхом интервјуисања, условима интервјуа и могућностима за одустајање, уколико то у било ком тренутку пожеле. Намерно бирани узорак за ово истраживање чинили су наставници и стручни сарадници у школама у статусу ментора или приправника. Иако смо се у одређивању узор каментора руководили основним критеријумом да наставниции стручни сарадници у својој пракси имају менторско искуство које није старије од три године, у изабраном узорку били су у највећем броју ментори који су у тренутку истраживања обављали ову праксу, а само у три случаја је та пракса везана за неку од претходне две школске године. У том смислу, обезбеђена су сасвим свежа сећања и увиди у праксу која је реализована. Обављено је 20 интервјуа (видети: Масон, 2010) са 10 парова приправника и ментора, у укупном трајању од 22 и по сата. $\mathrm{C}$ обзиром на то да су за овај рад релевантни подаци који су добијени у интервјуима са 10 ментора, помињемо и то да се просечна дужина трајања интервјуа са њима кретала у распону од 55 до 95 минута, а да је укупно време трајања свих интервјуа 10 сати и 56 минута. Аудиозаписи интервјуа транскрибовани су на 317 страна текста, који је послужио као основа свих даљих анализа. Теренски део истраживања остварен је у периоду од 2. априла 2014. до 29. маја 2014. године.

Истраживање је резултирало релевантним налазима у оквирима постављеног истраживачког оквира, али и једним бројем налаза на које нисмо били директно истраживачки усмерени. Реч је о налазима добијеним у интервјуима са менторима, који сугеришу емпиријски засновану типологију у оквиру које се издвајају три могућа типа менторства код нас. До типологизације се дошло тако што је развијен специфичан, контекстуално испровоциран метод, а да то уопште није била првобитна намера истраживача. Наиме, наша пажња била је усмерена на начине на које су ментори разумевали, тумачили и коментарисали издвојене проблеме у вези са менторством, без развијене полазне идеје о томе: 
- да ће неки од тих начина разумевања чинити унутрашње веома конзистентне обрасце;

- да ће уочени обрасци бити толико „удаљени” једни од других да могу да чине обрисе посебних типова менторстава.

У складу са чињеницом да није постојала почетна намера истраживача да открије различите типове менторског рада, није постојао ни унапред осмишљен начин на који би се евентуална типологизација откривала. Она се (као последица увиђања) „појавила” услед вишебројног читања наратива ментора у целини, а у виду конзистентних структура и кохерентних идеја које су у свести истраживача полако почеле да се обликују у „портрете” различитих ментора, а који су потом били кориштени као основни материјал даље анализе и интерпретације. Даљом анализом наратива издвојена су три типа ментора међусобно најудаљенија по разумевању основних концепцијских питања менторства (избор и прихватање менторства; функција менторског рада, очекивања од приправника; улоге приправника и ментора; ставови о учењу - ко учи, шта се учи и како се учи током овог периода; планирање рада) и конкретном опису начина рада са приправницима.

С обзиром на то да је методолошки приступ настајао током самог истраживања, а као резултат бављења прикупљеним подацима на начин на који то није било унапред планирано, првобитну бојазан и сумњу да трасирамо погрешан пут отклонили смо ставом Чемберленове о томе да су квалитативним методологијама потребни нови приступи (Chamberlain, 2012, str. 62, према Вилинг, 2015, str. 375). Наиме, ова ауторка сматра да су истраживачи у домену квалитативне парадигме већ дуже време склони да користе „методологије са полице”, тј. да „превелик број квалитативних истраживача има тенденцију да се ослања на методологије спаковане у приручнике, које могу да користе као већ готов производ, као што се користе рецепти" (Chamberlain, 2012, str. 62, према Вилинг, 2015, str. 375). Охрабрени идејом да се до резултата не долази увек (и свакако не искључиво) добро утабаним стазама, препустили смо се укупности прикупљеног материјала и расположивим методолошким знањима, са отвореношћу за све ново и неочекивано.

У извесном смислу, можемо рећи да је током нашег методолошког трагања процес откривања и давања смисла и значења издвојеним типовима менторског рада почивао на појму „херменеутичког круга" (Schmidt, 2006, str. 4), који подразумева међузависност делова и целине у процесу откривања значења и давања смисла нечему. У том контексту, свој „херменеутички круг” прошли смо тако што смо, настојећи да разумемо поједине исказе и рефлексије ментора о различитим аспектима менторског рада, постепено откривали целину, која је постајала ново штиво подложно другачијим аспектима анали- 
зе и разумевања. Та новооткривена целина повратно је уносила нови смисао и нудила значења неоткривена током покушаја разумевања појединачних делова. Овакав методолошки образац резултирао је у крајњем исходу дефинисањем три различита типа менторског рада, који су према својим кључним карактеристикама названи - ad hoc менторство, форма-менторство и развојно менторство.

\section{РЕЗУЛТАТИ И ИНТЕРПРЕТАЦИЈА}

Уз уважавање чињенице да су све поделе и типологизације у образовању веома условне и порозних граница, добијени наративи, како смо претходно већ објаснили, послужили су нам као основ за грађење контура три различита типа менторског рада у нашем образовању. Полазни оквир за разликовање ова три различита типа чинили су њихови различити, а често и међусобно супротни ставови о:

- функцији менторског рада;

- очекивањима од приправника;

- професионалним улогама које приписују приправнику и ментору;

- ставовима о учењу (ко учи, шта се учи и како се учи током овог периода);

- планирању рада;

- изворима мотивације да се буде ментор (Iancau-Haddad \& Oplatka, 2009).

У односу на уочене разлике и супротности у одговорима које су давали ментори, дефинисана су три могућа типа менторства: $a d$ hос, форма-менторство и развојно менторство.

Ad hoc менторство. Овај тип менторства могао би да се окарактерише и као менторство у ходу. Ментор је унутрашње мотивисан и подстакнут жељом да пренесе приправнику све што зна. Ипак, то је спреман да ради у време које није посебно одвојено за приправника, већ на одморима, у кратким разговорима или паузама. Ментор је у овом случају модел, сигуран у оно што ради, са изграђеним системом понашања који није спреман да мења, нарочито није спреман да мења тако што би учио од приправника. У оваквом моделу нема заједничког планирања рада, дефинисања тема и области којима треба да се баве приправник и ментор, нема бављења питањима шта су чије улоге и одговорности - јер се зна да је ментор учитељ, а приправник ученик. У складу са претходнонаведеним, нема ни праћења ни мењања постојеће праксе - јер се полази од претпоставке да је она пракса коју остварује ментор довољно добар узор који приправник треба да следи и репродукује. 
Заједнички рад постоји - али се своди искључиво на припрему и реализацију часова, што се препознаје и као добра прилика за учење приправника. У оваквим ситуацијама, приправник учи тако што посматра ментора и пита оно што му је нејасно, или тако што ментор директно указује на пропусте у раду приправника. У неким другим ситуацијама, које чине саставни део живота школе, али и грађења идентитета професије наставника (родитељски састанци; сарадња са колегама, укључивање у различите школске тимове), ретко се, или уопште, не препознају могуће прилике за учење.

Ментор води рачуна о томе да испуни све формалне захтеве који су му познати и да обезбеди да се приправник осећа вођено и подржано. Ипак, помоћ и овладавање професијом своди се на појединачне сегменте рада (нпр. - реализација неке наставне јединице), а идентитет наставника гради се искључиво на улогама које подразумевају „пренос” конкретних знања.

Ментор подстиче реализацију праксе која се обавља на основу представа о томе како би требало да се ради, а не на основу јасних знања и преиспитивања постојећих представа. Уопштено гледано, овакво менторство ствара много више шанси за успешно реплицирање, него мењање и развијање постојеће праксе.

Кратак извод из наратива ментора који је послужио као основа за креирање описа модела:

M1: Директор ме питао... он ме питао да ли бих желела, да ли пристајем да будем неком ментор и ја сам рекла „да” зато што је мени свеједно да ли ми је неко на часу или ми није на часу, ја увек радим исто... а знајући то да сам ја имала мало праксе као приправник, ја сам желела њој да помогнем. Мени је свеједно да ли ћу добити овога или онога, а све зависи од њих - колико они желе.

Мени то није одузимао неко велико време, јер у принципу ја само преносим своје знање њој. Менторство служи да се припреме и образују добри кадрови и да се помогне младим људима, јер ти (приправник, прим. аут.) добијеш наставне јединище, добијеш Годишњи план и наставне јединице и онда ти те наставне јединице треба да обрадиш на часу, али постоји проблем у томе што нису све наставне јединице истог обима и онда ти мораш да ускладиш где ћеш ита да радиш, да скратии, да убаииш.

Њено је да слуша и да учествује, јер ако ја сада њој причам и објашњавам шта треба да ради, а она то не прихвати и не чује, или чује, па као да није ни чула, онда ништа нисмо урадиле. Ментор треба да упућује приправника на то како и шта радити, то му је улога, а приправник је ту да поставља питања и да прати то што се ради. У свему томе, приправник учи како на најлакши и најбољи начин може представити неку наставну јединииу, како се то у школи на најбољи 
начин ради, учи на који начин то најбоље представити и каква је пракса у ствари. А, учила је тако што јој ја кажем: „Крећеш час тако, тако и тако, па онда убачи то, па то, па можеш припремити слике и презентацију итд. Ја сам је упућивала, онда би она дала неки свој предлог, и ја кажем „Да можеш то, или не немој тако”. И она је слушала и мени је то значило... али ја нисам нешто учила од юе, али сам приметила да је добра са рачунарима, да би ето можда, касније ја могла то да усавршим на неком семинару.

Не, не... не мислим да треба правити дугорочни план. Ми смо то имале само за њен заврини час нпр., и, да, имале смо за још један. У приниипу, потребно је имати неки план шта и како радити које часове би било добро да она држи, који су најлакши за почетак, које су наставне јединище лакше. Али план као план нисмо имале. Ја и не волим те администрације и та писанија. То толико пискарағе по мени стварно нема смисла.

Форма-менторство. Овај тип менторства заснива се на магловитој представи о томе шта би менторски рад требало да буде и јасној намери да се одговори на све познате формалне захтеве. Овакво менторство почива на томе што је ментор спреман да помогне, али „неснађен" (несигуран) у својој улози. Део несигурности може бити узрокован чињеницом да је за ментора постављен као нужни, а нереални избор најбољег. Ментор из оквира овог типа није сигуран у то шта треба да ради, а сваку идеју која би представљала озбиљно бављење менторством одбацује (јер препознаје да се управо небављењем уклапа у културу установе у којој ради и тако мање професионално ризикује).

Овај тип ментора води рачуна о томе да формални захтеви менторства који су му познати буду испуњени (нпр. ,да буде написан завршни извештај о приправнику, да се посети прописани број часова и сл.). Оно што је овом типу ментора мање битно јесте начин на који ће ови захтеви бити испуњени. У том смислу, само испуњавање захтева не доводи у везу форму са суштином (нпр., ментор на чијим се опсервацијама и увидима заснива представљени тип менторског рада био је спреман да препише извештај о приправнику од неког другог ментора. На тај начин он је формално испунио захтев и није бринуо о томе шта је значај и функција писања овог извештаја, као ни шта је заиста улога ментора у овом процесу). Другим речима, у великом броју ситуација у раду са приправником, ментор бира да ради тек формално - да на папиру остави траг.

Циљ рада са приправником види у испуњавању формалних захтева који претходе полагању испита за лиценцу, а не стварању прилика за учење и развој. У ретким ситуацијама у којима заиста нешто ради са приправником, помаже му у оним деловима рада које препознаје као важне за наставничку професију (настава, оцењивање, де- 
журства). Волео би да је модел и узор свом приправнику, али је истовремено несигуран да то заиста и може да буде.

Овакво менторство може додатно да оптерећује, с обзиром на то да се на једној страни ослања на мито ментору као неком ко све зна, уме, може и не сме да погреши, а на другој на несигурност у сопствене снаге и компетенције да се буде баш такав ментор. У том смислу, посете часовима, када приправник посматра ментора, препознаје и тумачи као ситуације у којима не сме да погреши (имплицитно уверење о ментору као неком ко је непогрешив), а не као потенцијал из кога и ментор и приправник имају шта да науче.

Овај тип менторства могу да карактеришу и различите контрадикторности које се огледају у томе што се ментор не противи улози коју је добио, иако се у њој не осећа пријатно; свој рад са приправником не планира унапред, иако увиђа да би му то могло помоћи да ради квалитетније; не тражи помоћ од стручне службе, мада препознаје да би му она добро дошла.

Кратак извод из наратива ментора који је послужио као основа за креирање описа модела:

M2: Па, у принципу, у школи и није био нико други сем мене, подразумевало се да ћу ментор бити ја. Није ме нико морао ни питати, а да ли ме је питао или не, да ли ме је директор питао не могу рећи, не сећам се. Једноставно, подразумевало се, било је некако, тако, ништа... ништа. Некако ми је било важно само да обавимо ту формалност. Знао сам да ћу дати све од себе, показати јој све што будем могао... у принципу, помоћи ћу ја приправници колико год могу, али не могу ја њој помоћи, онако право. Чини ми се да цео тај систем и није осмишьен да би се неком помогло, него да би се та форма испунила. Мислим да свима одговара да се све своди на форму... ето и мени... одговара у смислу мање посла... јер ито је више обавеза, више ризикујете.

А видим и да сам то доживљавао као „увести човека у посао хемичара", па да положи тај испит и готово. Нисам ништа посебно ни очекивао од ње, не. Мислим, приправник од ментора треба да учи и то је то. Сматрам да би приправник требало да у ментора гледа, да нешто од њега научи. Како се држи час, однос са ученицима, одговарање на различите ситуачије, како се дежура, како се организују такмичења. Али ми је било тешко, кад ми дође на час, бринуо сам да нећу нешто погрешити, јер ја сам ментор, није ми баш свеједно да ли ће она отићи са часа и рећи „,па тако је рекао ментор", а да то нешто буде погрешно.

Па, нисмо уопште планирали. Сад гледам, у принципу ја вероватно нисам ни био спреман за то менторство, сад кроз ову причу са вама, ја у принципу видим да ја нисам ни био спреман, кад видим 
шта је све ту могло да се уради, ја у ствари нисам ни знао шта све може да се ради... Ето. Али, сви тако раде, и како раде сви, мораш и ти. Можеш мааало изнад, 5\% нпр., али не ништа радикално да мењаш, јер би се то онда тумачило као окренутост против, гарантујем то. Тако да, нисам се ни трудио... па да, нисам се ни трудио.

Развојно менторство. Иако свестан комплексности захтева који пред њим стоје и стално запитан хоће ли све моћи и умети, ментор је спреман и мотивисан да се бави приправником.

Приправника у исто време доживљава и као свог ученика, али и као млађег учитеља, од кога може да црпи знања, идеје, вештине и мотивацију да и са̂м учи ново и напредује на пољима која препознаје да су му слабије развијена. Иако су границе и садржаји менторскоприправничке праксе до краја неиспитани и не увек јасно препознатљиви, менторство се разуме и прихвата као шанса за обострани развој. У том је смислу функција менторског рада помагање младом колеги да открије разноврсност професије, али и померање сопствених професионалних граница.

Увиђа се важност планирања, не само у контексту организовања заједничког рада него и у смислу препознавања плана као полазне основе за евалуацију и вредновање заједничког рада и постигнутих резултата. У том смислу, ментор показује спремност да мења сопствену праксу у будућности (мењање оног што са једним приправником није урађено како се сада чини да је требало).

Наглашава се важност обављања различитих заједничких активности и обавезног разговарања о ономе што је урађено. Шансе и могућности за учење не виде се само у сфери међусобних разговора већ се премештају и на терен односа са другима у колективу - директором, ученицима, другим наставницима.

Осим развијања осећања припадности и прихваћености код приправника, важним се препознаје и развијање аутентичног професионалног идентитета приправника. У том смислу, од приправника се не очекује да само посматра и примењује већ да буде спреман да се аргументовано супротстави и иницира акцијеиактивности које могу унапредити постојећу праксу у установи.

Кратак извод из наратива ментора који је послужио као основа за креирање описа модела:

M3: Ја сам то менторство оберучке прихватила, била сам пресрећна када ме XY (особа која је била контакт између $М$ и П примедба интервјуера) позвала и питала да ли бих пристала.. ја с тим апсолутно, ни једног момента нисам имала проблем, ја сам опажала и личну добит од тога да ми неко млад дође, да ми да идеје, да ме покрене, да ми да нове енергије, да ме натера да неке ства- 
ри које сам можда ошљарила почнем да радим онако како треба. Ето, то је био мој мотив. То што сам видела да и ја поред ње могу да се развијам и напредујем. Али, стално сам се нешто питала, па сам гледала, знаш онај приручник Приправник и ментор, како ли се зове, некако сам стално бринула да ли ћу све да урадим, хоћу ли све да препознам.

Никад не заборављам да је то све време паралелно учење, али та мера, да је не угушим, то ми је био један проблем. Други ми је био, када тече неки свакодневни посао и ја речимо одем код директорке на минут и онда ту започне неки јако важан разговор због кога ја нисам ни дошла, али он је кренуо... и мени само у тренутку пролети да је врло битно да и приправнииа тај разговор чује, али ја то не могу да урадим, да прекинем разговор, или да је дозовем јер она нпр. није ту... ето, тако, било је драгоцених ситуачија у којима се она није нашла..то ми је јако жао...али сам је свесно упућивала и на друге колеге... да учи и од других.

Ја сам јој била и саветодаваи, сарадник и партнер да, сигурно, али и неки ауторитет, не баш гуруа и вође, али неки ауторитет, да. А мени су много значиле њене повратне поруке, то ми је мислим било најдрагоценије. Поготово ми је значило у тим неким пољима где се ја не осећам сигурно. Е, то је сад та свежина о којој сам ти већ причала, то је сада стварно тај један сараднички однос... да ми смо биле учитељи једна другој... Само, очекивала сам мало већу инииијативу са юене стране, то ми је фалило све време и то сам јој и рекла... стално сам говорила: „, (име), шта год хоћеш да радиш, само кажи".

Знаш, ми нисмо направиле нам план пролажења кроз њено приправништво, него се више она придодала на мој посао, на мој план, а чини ми се, то сада некако видим као највећи пропуст. E, сад свакакве си ми ти фиоке отворила... сада то освешћујем до краја. Сада бих сигурно направила тај план, са обавезним проласком на крају месеиа кроз испуњеност и дискусијом о томе шта смо урадиле, ита нисмо, зашто...

У Табели 1 наведене су сублимиране, основне карактеристике три различита типа менторског рада. 


\section{Табела 1. Приказ основних карактеристика три различита типа менторског рада}

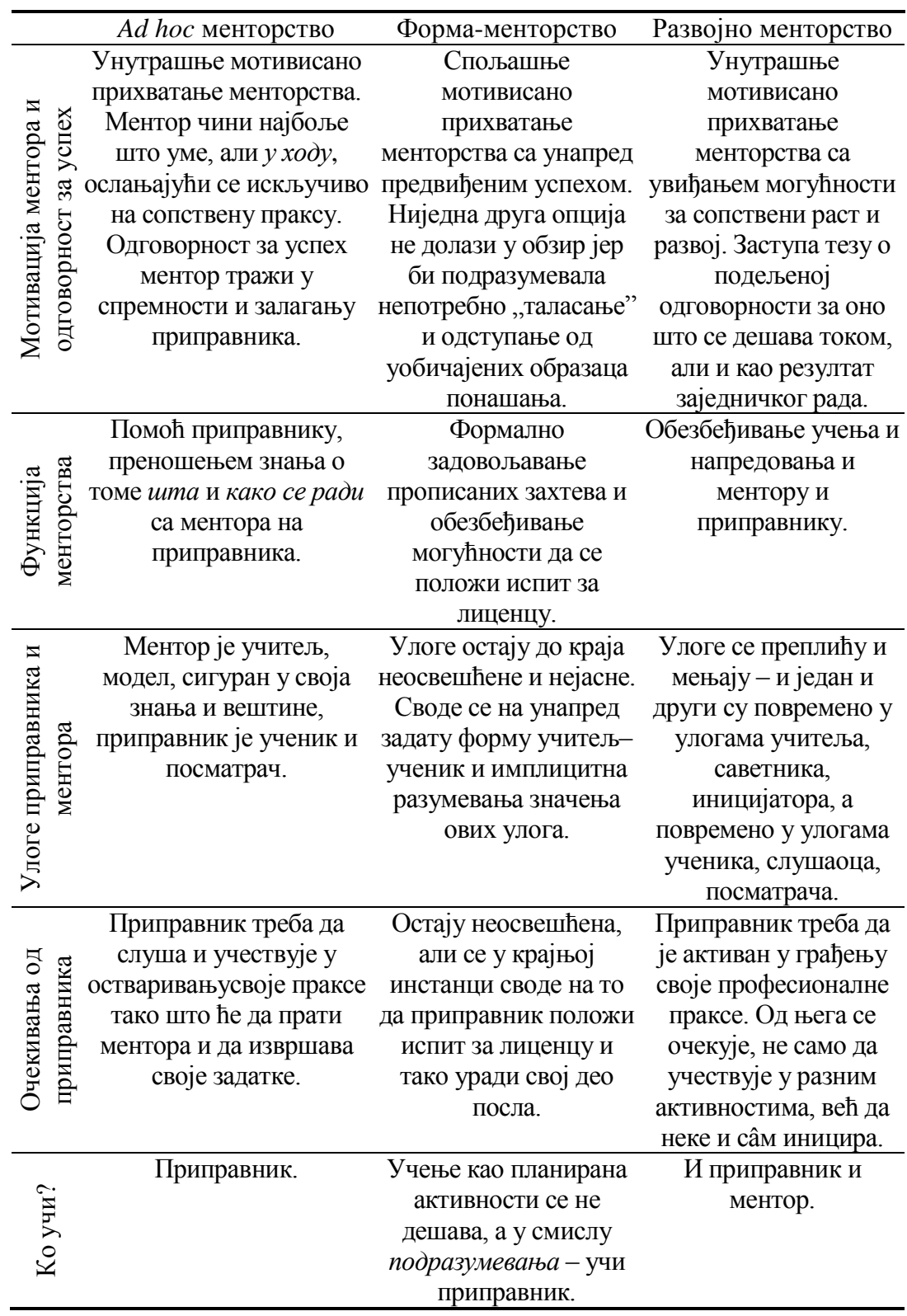




\begin{tabular}{|c|c|c|c|}
\hline & Ad hoc менторство & Форма-менторство & Развојно менторство \\
\hline 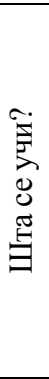 & $\begin{array}{c}\text { Поједини сегменти } \\
\text { професије, тј. Оно што } \\
\text { ментор препознаје као } \\
\text { најважније (нпр. - како } \\
\text { најбоље реализовати } \\
\text { неку наставну } \\
\text { јединицу). Изостаје } \\
\text { учење о професији и } \\
\text { разноврсним улогама } \\
\text { које је чине. }\end{array}$ & $\begin{array}{c}\text { Експлицитно - нешто } \\
\text { мало од онога шта и } \\
\text { како радити. } \\
\text { Имплицитно - да је } \\
\text { могуће импровизовати } \\
\text { испуњавање обавеза у } \\
\text { образовању. }\end{array}$ & $\begin{array}{c}\text { Различити сегменти } \\
\text { професије, као и са̂м } \\
\text { приступ професији у } \\
\text { смислу неговања } \\
\text { запитаности, провере и } \\
\text { рефлексије над својом } \\
\text { праксом. }\end{array}$ \\
\hline 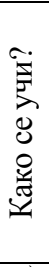 & $\begin{array}{c}\text { Учи се по моделу или } \\
\text { тако што ментор } \\
\text { упућује, подучава и } \\
\text { скреће пажњу на оно } \\
\text { што треба поправити, а } \\
\text { приправник примењује } \\
\text { предложене корекције. }\end{array}$ & $\begin{array}{c}\text { Када се препознаје } \\
\text { могућност за учење, оно } \\
\text { се одвија искључиво по } \\
\text { моделу или преношењу } \\
\text { образаца (понашања, } \\
\text { делања...) }\end{array}$ & $\begin{array}{c}\text { Комбинацијом } \\
\text { разноврсних модела и } \\
\text { начина: разговором, } \\
\text { причом, из литературе, } \\
\text { искуствено, по моделу, } \\
\text { суочавањем... }\end{array}$ \\
\hline 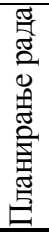 & $\begin{array}{c}\text { Не планира се унапред } \\
\text { и не препознаје се } \\
\text { важност планирања - } \\
\text { јер се учи у ходу и од } \\
\text { онога који зна како } \\
\text { треба. } \\
\end{array}$ & $\begin{array}{c}\text { Не планира се, jep ce } \\
\text { планирање и не } \\
\text { препознаје као део } \\
\text { менторско- } \\
\text { приправничке праксе. }\end{array}$ & $\begin{array}{c}\text { Препознаје се важност } \\
\text { дугорочног планирања } \\
\text { с аспекта реализације и } \\
\text { евалуације заједничког } \\
\text { рада. }\end{array}$ \\
\hline
\end{tabular}

\section{ЗАКљУЧНА РАЗМАТРАЬА}

Упркос чињеници да савремени теоријски концепти менторство посматрају као процес од кога и приправници и ментори могу да имају професионалну корист и који потенцијално може да послужи као полуга развоја целе установе, представљени резултати рада говоре у прилог чињеници да се овакви полази могу прихватити или одбацити тек конкретним довођењем у везу са начинима на које сами ментори разумеју своју и приправникову улогу, као и функцију и значај укупности менторског рада.

У том смислу, рад представља корак у осветљавању чињенице да се, упркос јединствено важећим документима којима се дефинишу основни елементи концепције приправништва и менторства у образовним установама у Србији, начин разумевања ових елемената и њихово „превођење” у праксу, као и имплицитне теорије о томе шта менторство јесте и чему треба да служи - разликују од ментора до ментора. Типологизација понуђена у раду сугерише да концепција садржана у основним документима којима се регулише приправништво и менторство у Србији - може да се разуме и реализује на најмање три различита начина. Оно што уочене разлике у раду ментора неминовно носе са собом јесу потенцијално различити ефекти за развој и разумевање професије од стране приправника са који- 
ма раде. Другим речима, сваки од описана три типа менторског рада носи сасвим специфичан потенцијалза обликовањеновихнаставника.

У том смислу, ментор који се поставља као модел и узор, а рад са приправником своди на реализацију наставе - шаље поруку да је суштина професије наставника садржана у остваривању наставних јединица (остављајући многе друге области рада наставника потпуно неоткривене - нпр., сарадња са колегама и родитељима, остваривање ваннаставних и ваншколских активности итд.); ментор који свој рад са приправником своди на задовољавање форме непланирано учи приправника да је и то начин на који је могуће обављати рад у школи; коначно, ментор који праксу заснива на промишљању о свом и заједничком раду са приправником своју менторску праксу приближава оној коју сугеришу Харгривс и Фулан (Hargreaves \& Fullan 2009) и у којој препознају потенцијал за промену установе изнутра. Дакле, тек оно менторство које подразумева активности у којима ментори граде свој идентитет кроз интеракцију са приправником приближава се ономе што горепоменути аутори препознају када пишу о менторству као саставном делу професионалне културе школе.

Поменимо на крају да намера овог рада није да се типологија препозната у истраживању уопшти на све менторе и различите образовне контексте. Њен допринос пре свега видимо у корисној допуни постојећем разумевању менторског рада и искустава, као и могућностима даљег истраживања применљивости типологије у различитим образовним контекстима. Потенцијална вредност понуђене типологизације у том смислу огледа се пре свега у томе што самим менторима може да послужи за препознавање властитих доминирајућих идеја о важним питањима менторства и јаснијем сагледавању професионалног усмеравања приправника којем оне воде. Осим тога, указивање на могуће другачије ставове и виђења, са којима би њихова аутентичност могла да се пореди и/или доведе у питање - отвара могућност менторима за даље учење о себи као професионалцима.

Осим ових, у нешто ширем контексту сагледано, истраживање сугерише и могуће смернице за развој постојеће праксе: програме факултета који образују будући наставни кадар требало би конципирати тако да се обезбеди упознавање са основним концептима и постулатима менторског рада; на нивоу система образовања у Републици Србији ваљало би обезбедити усаглашеност идеја и концепата базичног образовања и идеја и концепата приправништва и менторства; треба промовисати и јасније афирмисати концепцију приправништва и менторства и теоријских оквира на којима она почива; обезбедити обуке за менторе на којима би различите приступе менторском раду било могуће излагати и сучељавати једне са другима; али и обезбедити непрестану, системску подршку приправницима и менторима током праксе коју заједно спроводе у циљу обезбеђивања уједначених услова за развој и спровођење исте. 


\section{ЛИТЕРАТУРА}

Britton, E., Paine, L., Pimm, D., \& Raizen, S. (Eds.). (2003). Comprehensive teacher induction. Dordrecht: Kluwer Academic Publishers

Grupa autora (2009). Mentor i pripravnik - Vodič za nastavnike, vaspitače i stručne saradnike [Mentor and trainee - Guide for teachers, educators and professional associates], Beograd: ZUOV.

Hargreaves, A., Fullan, M., (2009).Mentoring in the New Millennium. Theory into practice, Vol 39 (1), 50-56.

Higgins, M., Kram, K. (2001). Recoceptualizing mentoring at work: A developmental network perspective.Academy of Management Review, 26(2), 264-288.

Iancau-Haddad, D., Oplatka, I., (2009). Mentoring Novice Teachers: Motives, Process and Outcomes from the Mentor s point of View.The new Educator, No5, 45-65

Inzer, L., Crawford, C.B. (2005).A Review of Formal and Informal mentoring: Process, Problems and Design. Journal of Leadership Education, 4(1), 31-50.

McGaw, B. (Eds.). (2005). Izveštaj OECD: Nastavnici su bitni: Kako privući, usavršavati i zadržati efikasne nastavnike

Mason, M., (2010).Sample Size and Saturation in PhD Studies Using Qualitative Interviews, Forum: Qualitative social research, 11 (3). doi:http://dx.doi.org/ 10.17169/fqs-11.3.1428

Maynard T., Furlong, J., (1995). Learning to teach and models of mentoring. U: Kerry T., Shelton M. A.: Issues in mentoring. Routledge. London.

Pravilnik o dozvoli za rad nastavnika, vaspitača i stručnih saradnika [Rulbook on work licence for teachers, educators and professional associates], „Službeni glasnik RS”. 22 (2005) i 51 (2008)

Sahlberg, P., (2013). Finske lekcije [Finnish lessons]. Beograd. Novoli.

Schmidt, L. (2006). Understanding hermeneutics. Stocksfield. Acumen Publishing. doi: 10.1017/UPO9781844653043

Seidman, I., (2006).Interviewingas Qualitative Research. A Guide for Researches in Education and the Social Sciences.Teachers College, Columbia University, New York and London

Sirpa, P., Raija, E., (2012).Dialogical Mentoring in the Supervising of Student Teachers Practice. International Journal for Cross-Disciplinary Subjects in Education, 3(1). 635-639.

Sundli, L., (2007).Mentoring - a new Mantra for education? Teaching and Teacher education. (23) 2, 201-214. doi.org/10.1016/j.tate.2006.04.016

Stansbury, K., Zimmerman, J. (2000).LifelinestotheClassroom: Designing Support for Beginning Teachers. San Francisco:WestEd.

Šijaković, T. (2013a). Mentorski rad u obrazovanju [Mentoring in Education], Pedagoška stvarnost (4), N. Sad, 604-617: God. 1, br 1 (1955) Novi Sad

Šijaković, T., (2013b). Mentorstvo kao model učenja tokom profesionalnog usavršavanja nastavnika [Mentoring as Learning Model During the Professional Development of Teachers], Inovacije u nastavi, Beograd, 83-93. God. 1, br 1, Beograd

Tillema H., H., Smith, K., Leshem, S., (2011).Dual Roles- conflicting purposes: a comparative study on perceptions on assessment in mentoring relations during practicum. European Journal of teacher education. Routledge.34(2), 139-159.

Veenman, S., (1984).Perceived Problems of Beginning Teachers, Review of Educational Research, 54(2), pp. 143-178.

Viling, K., (2016). Kvalitativna istraživanja u psihologiji [Introducing Qualitative Research in Psychology], Beograd: Clio

Zakon o osnovama sistema obrazovanja i vaspitanja, Službeni glasnik RS, broj 72 (2009), 52 (2011) i 55 (2013). 


\title{
MENTORING IN EDUCATION - THE CONTOURS OF POSSIBLE TYPOLOGIES
}

\author{
Tanja Šijaković \\ Institute for Improvement of Education, Belgrade, Serbia
}

\begin{abstract}
Summary
We carried out a research which focuses on the issues of internship and mentoring in education. Starting from the complexity of the selected object of research, we chose a qualitative research paradigm and the technique of semi-structured interviews. 20 interviews were conducted (Mason, 2010) with 10 pairs of interns and mentors, with total duration of 22.5 hours. Audio recordings of interviews transcribed on 317 pages of text and served as the basis for all further analyzes. Although our attention was focused primarily on the issues related to understanding the conceptof internships and mentoring and how the offered solutions would reflect in the practice of interns and mentors, research has unexpectedly resulted in some additional findings - the possible types of mentoring in our educational context. The shown results were achieved after the analysis of the transcribed material collected in individual interviews, conducted by ten mentors. All the discovered and different approaches to mentoring work are based on an analysis of responses and interpretations that were given by the mentors themselves, and related to: understanding the functions of mentoring; expectations from the interns; understanding the role of interns and mentors; understanding the process of learning and the importance of planning the work with interns. Interpreting the way mentors understand the aforesaid and describing specific relation with their interns, we have selected mentors who have demonstrated a consistent linguistic-experiential patterns and positions, mutually so different, that they can make the contours of different types of mentoring. In the paper these specific types are identified as: ad hoc, formal and development mentoring.

Ad Hoc mentoring could be characterized as a mentoring on the go. The mentor is motivated to teach interns all that he knows, but not in time that is specifically set aside for this, but during the breaks or short conversations between the classes. In this type of mentoring there is no joint planning, no discussing about the roles and responsibilities as it is known that mentor is a teacher, and intern is a student. The intern learns by watching a mentor and ask him what is unclear, or by mentor directly points to weaknesses in the work of interns. This kind of mentoring creates a lot more opportunities for replication, but to change and develop existing practices. Formal type of mentoring is based on a foggy idea of what mentoring should be, and a clear intention to respond to all known formal requirements. The goal of mentoring is understood as fulfilling the formal requirements which precede the exam for a teaching license, but not as creating opportunities for situational learning and professional development. This type of a mentor is willing to help, but insecure in his role. Usually, he is not sure what to do with intern, and cares only about formal mentoring request, which are known to him. In development mentoring: mentor is aware of the complexity of the mentoring work and constantly asked whether he might succeed, but motivated and willing to deal with intern. Mentoring is understood as an opportunity for mutual development. Intern is not expected to just observe and apply, but be prepared to confront the arguments and initiate activities that can improve the existing practice.

The paper is a step in highlighting the fact that, despite the unique valid documents which define the basic elements of the concept of internships and mentoring in educational institutions in Serbia, a way of understanding these elements and their "translation" into
\end{abstract}


practice, as well as implicit theories about what mentoring is and what is supposed to serve, differ from mentor to mentor. The typology offered in the work suggest that concepts contained in the basic documents governing internships and mentoring in Serbia, can be understood and implemented in at least three different ways. In this regard, the potential value of offered typology is reflected primarily in the fact that the mentors can use it to identify their own dominant ideas about important mentoring issues and clearer perception of professional pats in which they lead their interns. 